\title{
The Influence of Ottoman Empire on the conservation of the architectural heritage in Jerusalem
}

\author{
Ziad M. Shehada \\ University of Malaya \\ E-mail:archzms@gmail.com \\ DOI: $10.18326 /$ ijims.v10i1.127-151
}

\begin{abstract}
Jerusalem is one of the oldest cities in the world. It was built by the Canaanites in 3000 B.C., became the first Qibla of Muslims and is the third holiest shrine after Mecca and Medina. It is believed to be the only sacred city in the world that is considered historically and spiritually significant to Muslims, Christians, and Jews alike. Since its establishment, the city has been subjected to a series of changes as a result of political, economic and social developments that affected the architectural formation through successive periods from the beginning leading up to the Ottoman Era, which then achieved relative stability. The research aims to examine and review the conservation mechanisms of the architectural buildings during the Ottoman rule in Jerusalem for more than 400 years, and how the Ottoman Sultans contributed to revitalizing and protecting the city from loss and extinction. The researcher followed the historical interpretive method using descriptive analysis based on a literature review and preliminary study to determine Ottoman practices in conserving the historical and the architectural heritage of Jerusalem. The research found that the Ottoman efforts towards conserving the architectural heritage in Jerusalem fell into four categories (Renovation, Restoration, Reconstruction, and Rehabilitation). The Ottomans
\end{abstract}


focused on the conservation of the existing buildings rather than new construction because of their respect for the local traditions and holy places.

Yerusalem adalah salah satu kota tertua di dunia. Dibangun oleh orang-orang Kanaan pada 3000 SM, kota ini menjadi kiblat pertama umat Islam dan merupakan tempat suci ketiga setelah Mekkah dan Madinah. Kota ini diyakini sebagai satu-satunya kota suci di dunia yang dianggap penting secara historis dan spiritual bagi umat Islam, Kristen, dan Yahudi. Sejak didirikan, kota ini telah mengalami serangkaian perubahan sebagai akibat dari perkembangan politik, ekonomi dan sosial yang memengaruhi pembentukan arsitektur melalui periode-periode berturut-turut dari awal menuju era Ottoman, yang kemudian mencapai stabilitas relatif. Penelitian ini bertujuan untuk menguji dan meninjau mekanisme konservasi bangunan arsitektur selama pemerintahan Ottoman di Yerusalem selama lebih dari 400 tahun, dan bagaimana Sultan Ottoman telah berkontribusi dalam merevitalisasi dan melindungi kota dari kehilangan dan kepunahan. Peneliti mengikuti metode interpretif historis dan analisis deskriptif berdasarkan tinjauan literatur dan studi pendahuluan untuk menentukan praktik Ottoman dalam melestarikan warisan sejarah dan arsitektur Yerusalem. Penelitian ini menemukan bahwa upaya Ottoman ke arah pelestarian warisan arsitektur di Yerusalem jatuh ke dalam empat kategori (Renovasi, Restorasi, Rekonstruksi dan Rehabilitasi). Ottoman berfokus pada konservasi bangunan yang ada daripada konstruksi baru, karena rasa hormat mereka terhadap tradisi lokal dan tempat-tempat suci.

Keywords: Jerusalem; Ottomans; Restoration; Renovation; Reconstruction; Rehabilitation

\section{Introduction}

Historians have agreed that no other city has achieved more importance among the peoples on the earth than Jerusalem, especially for the adherents of the three monotheistic religions. ${ }^{1}$ Jerusalem is one of the most attractive cities in the world for travelers, explorers, pilgrims, and scholars. There is,

\footnotetext{
${ }^{1}$ Sylvia Auld \& Robert Hillenbrand, Ottoman Jerusalem: the living city, 1517-1917, London: Altajir World of Islam Trust, 2000, 55-59.
} 
thus, a large outstanding library of manuscripts, paintings, photographs, documents, and maps of the city. ${ }^{2}$

The Ottomans entered Jerusalem peacefully on $28^{\text {th }}$ December 1516 where the 'ulama (scholars) and pious men met Sultan Selim I and handed him the keys of the Dome of the Rock and Al-Aqsa Mosque. ${ }^{3}$ Hence, Jerusalem became a city of the Ottoman Empire and remained in their hands for almost four centuries. At the beginning of the Ottoman Empire, Palestine was part of the wilayah (State) of Syria which included the sanjak (districts) of Jerusalem, Nablus, and Gaza. ${ }^{4}$ Because of the importance of Jerusalem, the Ottomans paid more attention to it, separating it from the wilayah of Syria and linking it with the capital of Istanbul directly to expedite administrative transactions. ${ }^{5}$

In those successive periods, conservation for cultural heritage in the city was executed by the Ottoman sultans, beginning with Sultan Selim I in 1516 until the downfall of the Ottoman Empire in 1917 . However, one of the famous sultans fascinated by Jerusalem was Sultan Suleiman Al- Kanûnî (the Magnificent), who conserved numerous monuments and antiquities after seeing the Prophet Mohammad (S.A.W.) in a dream urging him to attend to Jerusalem. His reign was called the Golden Age. ${ }^{?}$

\footnotetext{
${ }^{2}$ Mehmet Tütüncü, Turkish Jerusalem (1516-1917): Ottoman Inscriptions from Jerusalem and Other Palestinian Cities, Netherlands: Turkestan and Azerbaijan Research Centre (SOTA), 2006, 102-105.

${ }^{3}$ Basher Barakat, Al-Quds Ash-Shareef Fi Al-Ahd Al-Othmani, Damascus: Maktabah Dar Al-Fik, 2002, 113-114.

${ }^{4}$ Ruth Kark, American Consuls in the Holy Land, 1832-1914, Detroit: Wayne State University Press, 1994, 211.

${ }^{5}$ Evliya Celebi; Robert Dankoff \& Sooyong Kim, An Ottoman Traveller: Selections from the Book of Travels of Evliya Çelebi, London: Eland publishing limited, 2011, 77.

${ }^{6}$ Johann Büssow, "Ottoman reform and urban government in the district of Jerusalem, 1867. 1917", in Urban Governance Under the Ottomans: Between Cosmopolitanism and Conflict, London: Routledge Publishers, 2014: 97-98.

${ }^{7}$ Robert Dankoff, From Mahmud Kaşgari to Evliya Çelebi, Istanbul: Isis Press, 2008, 104-105.
} 
IJIMS: Indonesian Journal of Islam and Muslim Societies, Volume 10, Number 1, June 2020:127-151
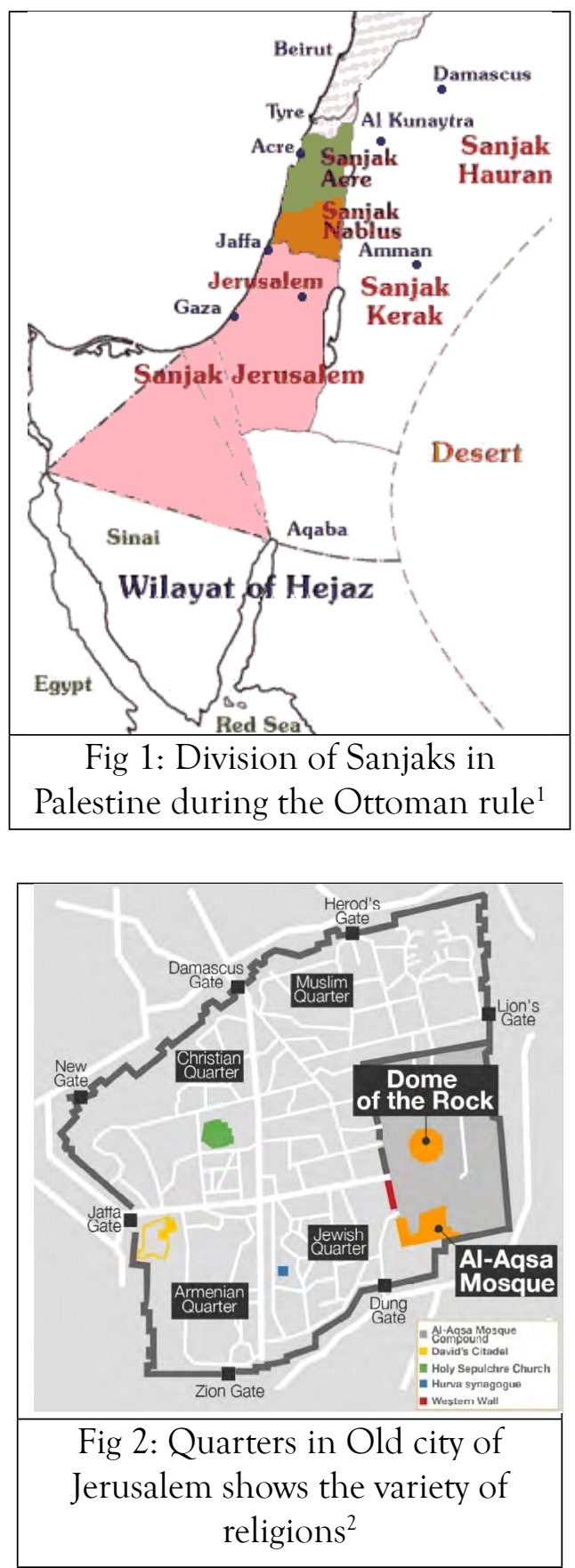


\section{Conservation of architectural heritage in Jerusalem}

There are many terms used in the conservation of architectural heritage. The researcher categorized Ottoman efforts and attempts exerted in Jerusalem into four categories which are the most important according to International Council on Monuments and Sites (ICOMOS, Monuments, $\&$ Sites). These four Rs are Restoration, Renovation, Reconstruction, and Rehabilitation.

\section{Restoration}

Restoration is "Returning the existing fabric to a known earlier state by removing accretions or by reassembling existing components without the introduction of new material". ${ }^{8}$ The Ottoman sultans were interested in restoring the monuments in Jerusalem, as a large part of the great construction projects were devoted to restoring and furnishing Al-Haram Al-Sharif (the Noble Sanctuary).

The Dome of the Rock accounted for the first massive construction works because it was the holy Central Building; according to an inscription removed from its position later, it was finished in 1528 by restoring 360 windows in the octagonal building and was ornamented with glassy pieces by order of Sultan Suleiman; hence, that year is considered the date of the comprehensive restoration in Islamic history. ${ }^{9}$ After completing the restoration, the exterior facades were decorated with colored Qachani in the style of great buildings in the capitals. ${ }^{10}$ The ornamentation did not comprise only decorating multi-colored mosaic pieces and colored glassy

${ }^{8}$ ICOMOS, The Burra Charter: The Australia ICOMOS Charter for Places of Cultural Significance 2013, Paris: International Council on Monuments and Sites publications, 2013, 33-35.

${ }^{9}$ Catraine Brebbia \& Vonda Echarri, Structural Studies, Repairs and Maintenance of Heritage Architecture XV, Southampton: WIT Press, 2017, 65-67.

${ }^{10}$ Ibrahim AbdulKarem, "Al-Mashhad Al-Umrani Fi Al-Quds Khilal Al-Ahd Al-Othmani.", Al-Tasamouh, Volume 18, Number 1 (April 2007), 287-298. 
tiles with non-tapered edges but also included drawings on the tiles topped with a transparent glaze layer. This can be linked to the Mosaic ornaments with the inscription dated back to 1545 and shows the high-level cost for tile decoration. In 1564, Sultan Suleiman ordered the technicians to restore the eastern and western wooden doors of the Dome of the Rock and wrapped them in bronze. ${ }^{11}$

The Ottomans also restored Al-Haram Al-Sharif comprehensively and constructed many scattered facilities such as the stairs leading to the West North Bä'ikah (colonnade). During the reign of Sultan Mahmud II, specifically in 1817, the Dome of the Rock, the shrine of the Prophet Dawood, and Al-Aqsa mosque were restored again. He repaired the exterior marble of the Dome of the Rock and constructed Riwaq (portico) above the south qibla entrance. ${ }^{12}$.As well, in the rule of Sultan Abdulhamid II (1887), Al-Jadid (New) gate in the northwest of Jerusalem wall was opened to facilitate both access and exit to Jerusalem, also the South Bä'ikah (colonnade) for Al-Haram was restored. ${ }^{13}$ The restoration of Jerusalem's wall and gates continued throughout the Ottoman period.

Additionally, the minbar (pulpit) of Burhanuddin was restored during the reign of Sultan Abdulmejid I (1843 A.D.). This minbar was called later AlMizān (the scale) Dome. ${ }^{14}$ Moreover, Ribat of Perm Shawish is considered one of the most important Ribats; it is an unparalleled architectural component in Jerusalem built during the rule of Sultan Suleiman (1540 A.D.), renovated several times during the Ottoman periods, and finally named Al-Rașasiyyāh

${ }^{11}$ Robert Dankoff, From Mahmud Kaşgari to Evliya Çelebi, Istanbul: Isis Press, 2008, 109-110.

${ }^{12}$ Gideon Sulimani \& Raz Kletter, "Bone Considerations: Archaeology, Heritage, and Ethics at Mamilla, Jerusalem.", International Journal of Cultural Property, Volume 24, Number 3 (2017), 321-350.

${ }^{13}$ Thomas Thompson, Jerusalem in Ancient History and Tradition, London: Bloomsbury Publishing, 2004, 110-112.

${ }^{14}$ Yahaya Waziri, Tatawour Omrani Wa Turath Me'amari Fi Madinah Al-Quds Ash-Shareef, Cairo: Dar Thaqafiyyah Le-Nasher, 2005, 66-67. 
The Influence of Ottoman Empire on the conservation of the architectural heritage... (Ziad M. Shehada)

(lead) school. ${ }^{15}$ It is worth pointing out in this context that the majority of the projects' materials were brought from various parts of the Black Sea region and Anatolia then shipped from Izmir or Istanbul to Jaffa port to be transferred overland toward Jerusalem. In other projects, tiles were used for the restoration produced somewhere in Jerusalem, though no tile makers appear on the lists of craftsmen. ${ }^{16}$

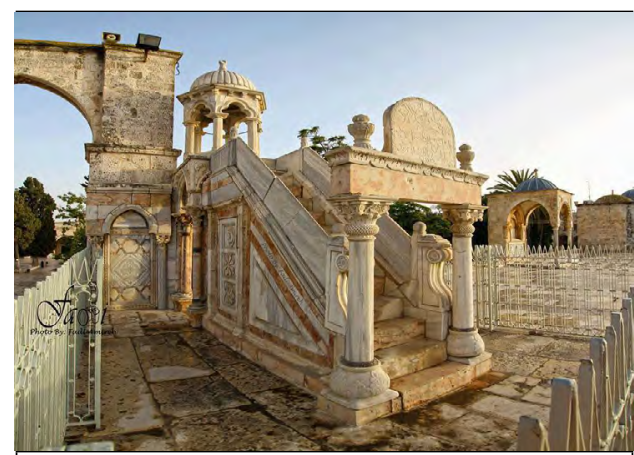

Fig 3: Burhanuddin pulpit after restoration $^{3}$

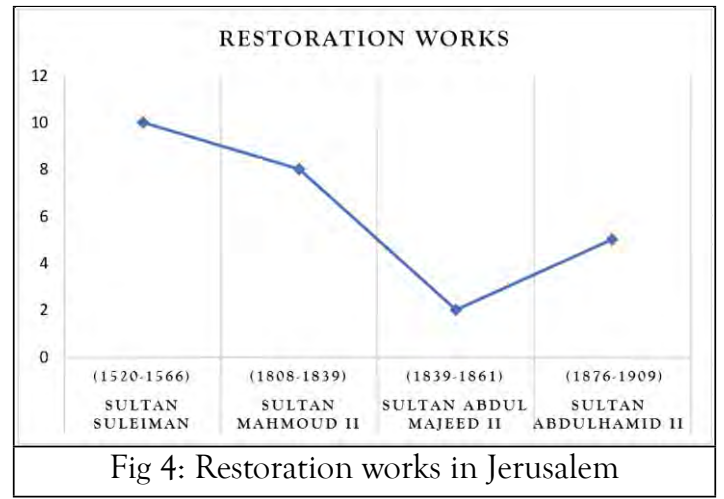

${ }^{15}$ Archie Walls, "Ottoman Restorations to the Sabil and to the Madrasa of Qaytbay in Jerusalem.”, Muqarnas, Volume 10, Number 2 (1993), 85-97.

${ }^{16}$ Giuseppe Rociola, "The Old City of Jerusalem between heritage and urban renewal: Public buildings and typological aspects”, Key Engineering Materials, Volume 628, Number 3 (2014), 21-26. 
According to the documentation, only four sultans were interested in the restoration works of Jerusalem. Sultan Suleiman was the top among the sultans. After more than 350 years, Sultan Abdulhamid II came again to retrieve the pledge of Ottomans towards Jerusalem

\section{Renovation}

Renovation is the improving of buildings by renewing and rendering them fresh or sound again. Renovating "allows one to change, modernize, adds bits and pieces and generally ends up looking nothing like the original". ${ }^{17}$ There were extensive large-scale renovations during the Ottoman period, when the Ottomans, particularly Sultan Suleiman, did a bunch of renovating operations in Al-Haram Al-Sharif. They maintained the walls, closed Al-Thahabi (golden) gate and opening Stna Mariam (Mary) gate, renewed Al-Qachani tiles located in Al-Selselah (chain) Dome in 1562, left inscriptions above the north gate called Al-Jannāh (paradise) gate, renovated the building stones in Prophet Dawood (David) tomb, and used dentate friezes for decorating the frames of doors, arches, and windows. ${ }^{18}$

Furthermore, the Ottomans made notable efforts in renovating the Dome of the Rock through successive periods. The most prominent renovation involved re-tiling the interior courtyard and exterior areas in 1546, renewing the Mosaics through many stages, and covering the outer drum of the dome with glazed tiles, which extended to cover the upper part of the Ottoman construction facades. ${ }^{19}$ The explicit pieces of evidence for those acts are the mosaic inscription found above the niche

\footnotetext{
${ }^{17}$ Catraine Brebbia \& Vonda Echarri, Structural Studies, Repairs and Maintenance of Heritage Architecture XV, Southampton: WIT Press, 2017, 75-76.

${ }^{18}$ Archie Walls, "Ottoman Restorations to the Sabil and to the Madrasa of Qaytbay in Jerusalem.”, Muqarnas, Volume 10, Number 2 (1993), 133.

${ }^{19}$ Mehmet Tütüncü, Turkish Jerusalem (1516-1917): Ottoman Inscriptions from Jerusalem and Other Palestinian Cities, Netherlands: Turkestan and Azerbaijan Research Centre (SOTA), 2006, 151-153.
} 
of Al-Selselah Dome. The inscription consists of two lines, of three meters in length, written in white on a brown floor coated with transparent glass, and suggests that the mosaic tiles had been renovated by order of Sultan Suleiman in $1562 .{ }^{20}$

According to Evliya Çelebi, the dome of Al-Qibli (southern) Mosque and its facades were restored by order of Sultan Suleiman, and he mentioned to Sarkhosh Abdo who renewed the niche and worked on constructing Suleymaniye mosque in Istanbul. ${ }^{21}$ At the same time, Sultan Suleiman renovated many of Al-Haram gates: Al-Sahera (earth's surface) Gate in 1537; Al-Khalil (Hebron) Gate in 1538, which had "La Ilaha Ila Allah, Ibrahim Khalilullah" (No God except Allah, Ibrahim his intimate friend) engraved over its facade; Al-Māghareba (Moroccans) Gate; the gate of Prophet Dawood (1540), which appears to be a military building as it is a huge stony minaret (defensive towers for control and protection, and has holes for launching arrows); Al-Amoūd (Column) gate above the ruins of gate-likely from the Crusader period; and finally Al-Asbāt (Tribes) Gate in (1538) shows Islamic military Ottoman features. ${ }^{22}$

After that and during the successive Ottoman periods, the lake of Sultan in the southwest of Jerusalem was renewed by Sultan Suleiman, ${ }^{23}$ while the wall of Khandaq (trench) in 1731 and Al-Qal'ah (Citadel) mosque in 1738 were renovated by Sultan Mahmud I. ${ }^{24}$ Also, Sultan Abdulmejid I

\footnotetext{
${ }^{20}$ Kent Schul, "Making Jerusalem Ottoman", In Living in the Ottoman Realm: Empire and Identity, 13th to 20th Centuries, USA: Indiana University Press, 2016, 97.

${ }^{21}$ Evliya Celebi; Robert Dankoff \& Sooyong Kim, An Ottoman Traveller: Selections from the Book of Travels of Evliya Çelebi, London: Eland Publishing Limited, 2011, 62-65.

${ }^{22}$ Mehmet Tütüncü, Turkish Jerusalem (1516-1917): Ottoman Inscriptions from Jerusalem and Other Palestinian Cities, Netherlands: Turkestan and Azerbaijan Research Centre (SOTA), 2006, 73-74.

${ }^{23}$ Susan Sinclair, Bibliography of Art and Architecture in the Islamic World (2 vol. set), Leiden: Brill publishers, 2012, 183-185.

${ }^{24}$ Giuseppe Rociola, "The Old City of Jerusalem between heritage and urban renewal: Public buildings and typological aspects”, Key Engineering Materials, Volume 628, Number 3 (2014), 21-26.
} 
renewed the Dome of the Rock again and added some decorations and inscriptions in 1852 whereas Sultan Abdulaziz renovated the streets of old Jerusalem city and their markets and ordered to be tiled in $1863^{25}$ and repaired the wooden roof for the octagonal building and maintained Lead plates covering the wooden roof. Furthermore, during his reign, the floor of the mosque was tiled with marble, colored, glassy windows were installed, and the mosque walls were plated with marble in the lower part in 1874. ${ }^{26}$

In the period of Sultan Abdulhamid II, Sabil and Madrasa of Qaitbay (Mamluk Sultan) in Al-Haram courtyard were renewed in $1882^{27}$. However, the Dome of the Rock and Al-Aqsa Mosque were decorated with various ornaments and with Surat Yasin written on the tiles of the exterior octagonal facades, which still exists. Jerusalem streets were paved in $1885 .{ }^{28}$ The Also was renovated was Prophet Dome that referred back to the early Islamic periods. It was believed that Prophet Mohamed PBUH prayed as Imam with the prophets and the angels there. This dome consists of 8 marble columns topped with 8 tapered arches followed by an octagonal drum and considered a foundation of the dome. Therefore, Sultan Suleiman established a rectangular niche among columns in order to protect the dome. Later, the dome was restored in Sultan Abdulmejid I reign (1845 A.D. $)^{29}$.

\footnotetext{
${ }^{25}$ Ismail Patel, Virtues of Jerusalem: An Islamic Perspective, United Kingdom: Al-Aqsa Publications, 2007, 85-88.

${ }^{26}$ Maryvelma O'Neil, "One giant house': Civil society mobilisation and the protection of Palestinian cultural heritage and identity in Al-Quds Al-Sharif", Journal of Holy Land and Palestine Studies, Volume 17, Number 1 (2018), 87-113.

${ }^{27}$ Sylvia Auld \& Robert Hillenbrand, Ottoman Jerusalem: the living city, 1517-1917, London: Altajir World of Islam Trust, 2000, 85-87.

${ }^{28}$ Vincent Lemire; Catherine Tihanyi \& Lys Weiss, Jerusalem 1900: The Holy City in the Age of Possibilities, United States: University of Chicago Press, 2017, 142-144.

${ }^{29}$ Oleg Grabar \& Said Nuseibeh, The Dome of the Rock, Massachusetts: Belknap Press of Harvard University Press, 2006, 152-155.
} 
The Influence of Ottoman Empire on the conservation of the architectural heritage... (Ziad M. Shehada)

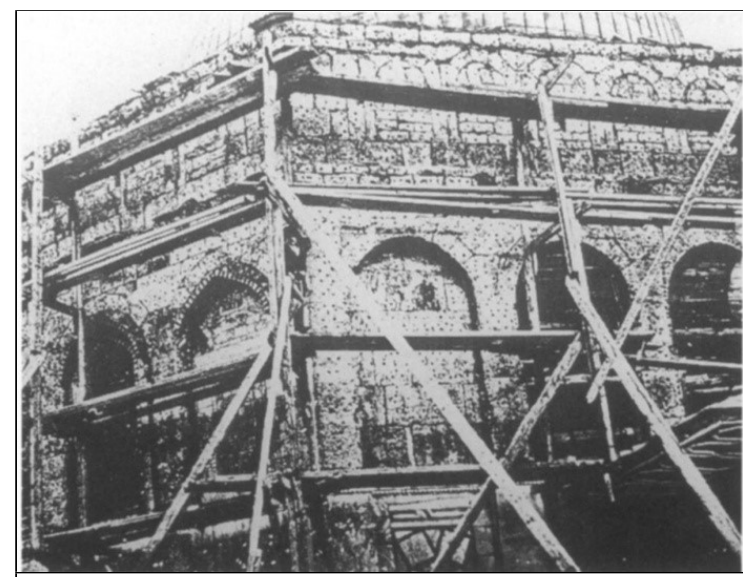

Fig 5: Exterior of west and southwest facades of the dome of the rock under renovation (1873-1875) $\mathrm{AD}^{4}$

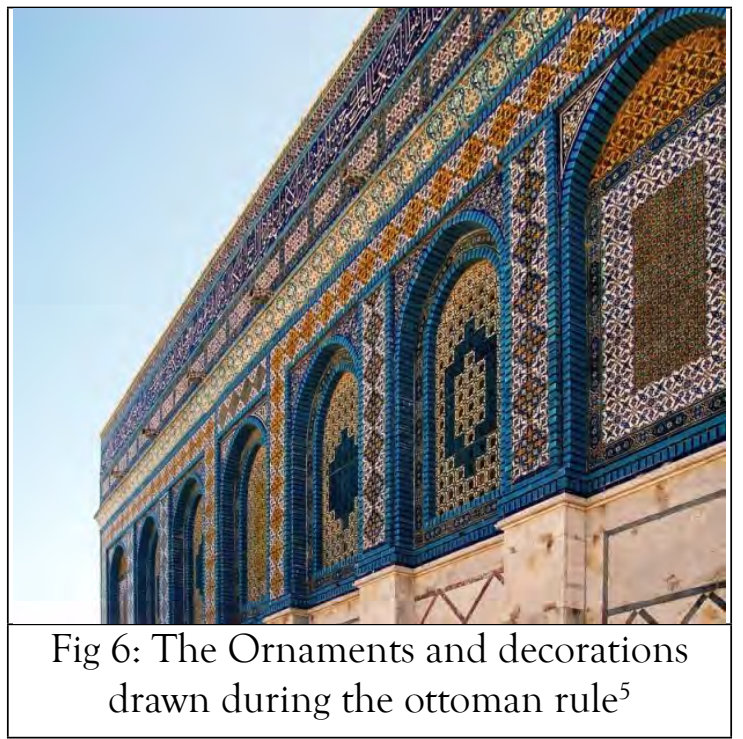

Likewise, one of the religious buildings renewed at the hands of the Ottomans is Indians zawiyah, which lies to the south of Al-Sahera Gate. It was renovated in 1870 , devoted to the poor and called Indians zawiya 
when some Indians had settled in. ${ }^{30}$ It consists of a huge architectural cluster, which was demolished and devastated more than once through to the 1967 war. Additionally, the Moroccan Zawiya was established in the Ayyubid period (1852) in the rule of King Al-Afdal bin Slaheddine and was renovated to be an appropriate place for worshipers ${ }^{31}$. Correspondingly, Al-Fakhriyah khanqah was built in 1330 and restituted, comprising a mosque for praying, places for Dua'a (supplication), and housing. ${ }^{32}$ Ultimately, Sultan Mehmed V developed Yusuf dome (south of the Dome of the Rock), it is a small Mosalla created in the reign of Salahuddin (1191 A.D.), the dome consists of a square building with a side length of two meters and opened into all directions except the south façade. ${ }^{33}$ Not only did the sultans renew and maintain the Islamic holy places, but they also paid attention to some holy places for Jews and Christians coming from all over the world to practice their worship freely. For instance, the Shrine of Jesus Church had no bells until 1545, so Sultan Suleiman ordered to hang bells inside. Also, there was a small building on the shrine in the circular section of the Church of the Holy Sepulchre, wherefore he ordered a suitable structure to be built instead of the old one. Also, by Sultan Ahmed III order in 1719, the majority of the drawings, figures, and styles in the Church of the Holy Sepulchre were preserved during the building of the bell tower, and many other restoration works were carried out. ${ }^{34}$

\footnotetext{
${ }^{30}$ ISESCO, Newsletter Issued by the Islamic Educational, Scientific, and Cultural Organization, Issues 82-88, Fes: ISESCO publishing center, 2010, 39-41.

${ }^{31}$ Robert Hillenbrand, The architecture of Ottoman Jerusalem: an introduction, London: Altajir World of Islam Trust, 2002, 122-124.

${ }^{32}$ Judy Hayden \& Nabil Matar, Through the Eyes of the Beholder: The Holy Land, 1517-1713, Leiden: Brill publishers, 2012, 161-163.

${ }^{33}$ Gabor Goston \& Bruce Masters, Encyclopedia of the Ottoman Empire, New York: Facts On File Incorporated, 2010, 82-83.

${ }^{34}$ Mohammed Ghūshah, Dirasah Me'mariyah Athariyah Tarikhiyyah: Harat As-Sa'adyah Fi Al-Quds, Ramallah: Syarikat Matba'ah Baitul Maqdis, 1999, 162-166.
} 

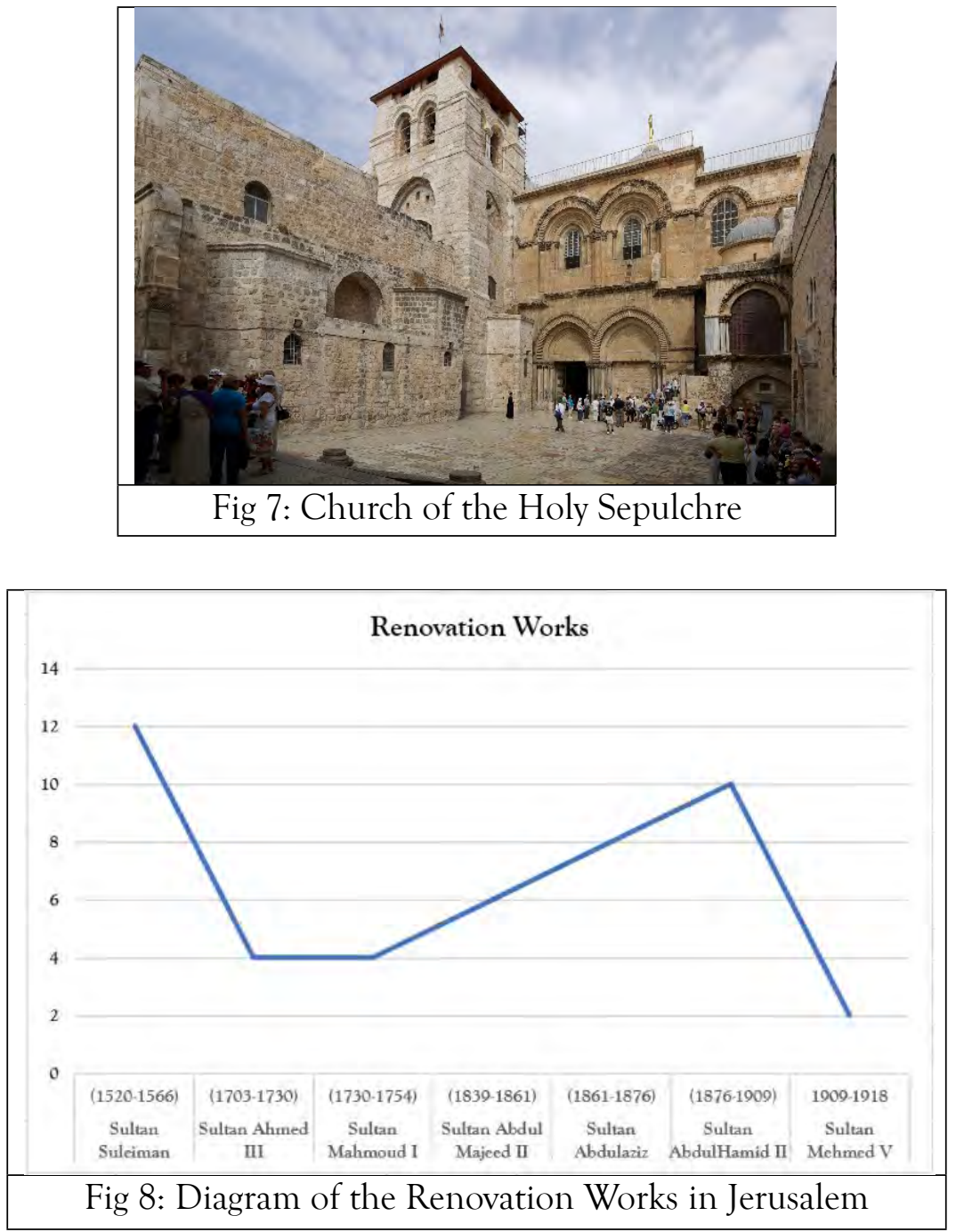

The diagram shows that many Sultans focused on the renovation of the holy city. However, it is like ebb and flow where the line hit the highest point in the time of Sultan Suleiman and moved up and down until the rule of Sultan Mehmed V. It is noreworthy that Sultan Abdulhamid II paid attention to Jerusalem following his grandfather's footsteps Sultan 
Suleiman and because of his belief that Islamic victory will come from the first Qibla.

\section{Reconstruction}

Reconstruction is "returning a place as nearly as possible to a known earlier state by the introduction of materials (old or new). This is not to be confused with either re-creation or conjectural reconstruction, which is outside the scope of conservation". ${ }^{35} \mathrm{~A}$ bulk of works in the reconstruction field was carried out by the Sultans through the Ottoman rule; one of them is rebuilding some parts of Dawood tomb which was completed in $1524 .{ }^{36}$ Likewise, Mohammad Bek (governor of Gaza) established a niche under the Dome of Dawood in the northwest of the Dome of the Rock and engraved a wonderful and precise frieze over it, and also used dentate friezes in several places inside Al-Haram wall, especially above and around the gates such as Al-Selselah, Al-Jadid, Gawānmah, and Al-'Atm (dark) gates in $1537 .{ }^{37}$ In accordance with the text inscribed on a window of Al-Aqsa Mosque, the constructive work performed by Sultan Suleiman in 1529 was not confined to Al-Aqsa Mosque, but extended to include Al-Haram entirely.

Nonetheless, while remaining interested in decorations and motifs, the Ottomans did not forget to fortify the city from surrounding dangers. Indeed, after completing the restoration of Al-Haram Al-Sharif, the first procedure was re-activating the defense system. Sultan Suleiman started by reconstructing the citadel located on the west side of the city. This citadel was restored in the early $14^{\text {th }}$ century after pushing the Crusaders

\footnotetext{
${ }^{35}$ Henry Cleere, Archaeological Heritage Management in the Modern World, England: Taylor \& Francis, 2012, 39-40.

${ }^{36}$ Katharina Galor \& Hanswulf Bloedhorn, The archaeology of Jerusalem: From the origins to the Ottomans, New Haven: Yale University Press, 2015, 87-88.

${ }^{37}$ Rivkah Frank, "Jerusalem Conference on the Digitisation of Cultural Heritage.", Library HiTech News, Volume 22, Number 1 (2005), 10-11.
} 
out of the Holy City. The citadel was ruined in the early $15^{\text {th }}$ century and was then unusable. Reconstruction was implemented in $1531 .^{38}$ At the end of 1532, Sultan Suleiman reconstructed a mosque in the southwest corner of the citadel with niche and pulpit for Friday prayers, and to serve as a landmark for Islam dominance, also built around the minaret of the mosque over the south minaret of the citadel. ${ }^{39}$ It may be inferred from the dentate friezes decorating the minaret that it was a part of the construction work which began in Jerusalem in 1524. Remarkably, there is a small round window overlooking the inner courtyard of a minaret from the north side, where its wide framework indicated one of the Mamlūk architecture elements prevalent in Damascus. ${ }^{40}$

Afterward, a huge project began to reconstruct the wall of the city, which was a conclusion of the crucial stage in the history of the Islamic city. The Ayyūbid commander Salahuddin renewed the city wall after recovering the city from the Crusaders in 1191, but it was ruined after about 30 years under the pretext of exposing the city to crusade siege risk in 1219, and later destroyed again in $1227 .{ }^{41}$ Thus, the city remained more than three subsequent centuries without a defensive system, Sultan Selim I started reconstructing the wall, but he died before its completion. Later, Sultan Suleiman ordered, in 1537, a new wall to be built, which was achieved in just four years, and exactly above the foundations of the dilapidated building. ${ }^{42}$

${ }^{38}$ Johann Büssow, "Ottoman reform and urban government in the district of Jerusalem, 1867. 1917", in Urban Governance Under the Ottomans: Between Cosmopolitanism and Conflict, London: Routledge Publishers, 2014, 141-142.

${ }^{39}$ Michael Dumper \& Craig Larkin, "The politics of heritage and the limitations of international agency in contested cities: A study of the role of UNESCO in Jerusalem's Old City.", Review of International Studies, Volume 38, Number 2 (2011): 25-52.

${ }^{40} \mathrm{Nimrod} L u z$, The Mamluk City in the Middle East: History, Culture, and the Urban Landscape, Cambridge: Cambridge University Press, 2014, 17-22.

${ }^{41}$ Adam Ishmael, The Acclaimed Writings of Truth, Indiana: Xlibris Corporation, 2016, 110-113.

${ }^{42}$ Sylvia Auld \& Robert Hillenbrand, Ottoman Jerusalem: the living city, 1517-1917, London: Altajir World of Islam Trust, 2000, 101. 
The steps of the reconstruction can be identified based on 13 inscriptions on the different sides of the wall. The reconstruction began in 1537 from the northwest wing, as indicated by three inscriptions on Al-Amoūd Gate, the middle minaret (defensive tower), and Al-Laqlaq (stork) located in the northeast corner of the wall. In the subsequent year, the work continued in the east side from the Al-Asbăt gate until the northeast corner of Al-Haram, in addition to the north part of the western city wall. ${ }^{43}$ Four inscriptions were dated to 1538 on the north and south minarets and two on Al-Khalil Gate. The last stage was the south part of the wall, and was finished in 1540, as mentioned in four inscriptions: two located on the Dawood gate, one on the Kabrit (sulfur) minaret located at the southeast corner, and the last on Al-Maghäribah gate. ${ }^{44}$ The wall has a length of about $4 \mathrm{~km}$ and average height of $12 \mathrm{~m}$, and also consists of 12 gates, 7 of which are currently opened, under the well-known names: from the South Al- Maghāribah and Nabi Dawood; from the west AlKhalil and Al-Jadid; from the north Al-Amoūd and Al-Sahera; and from the east Al-Asbăt gate. ${ }^{45}$ The remaining five gates are currently closed: in the east Al-Thahabi (golden) and Al-Janā'ez (funerals); and in the south Al-Monfarid (single), Al-Mozdawaj (double) and Al-Thulāthỉ (triple). The defensive system in the city wall was based on the Ayyubid and Mamluk models, similarly to Damascus wall built in the late Mamluk period, with defensive towers at the corners, and gates with zigzag entrances. The wall has 34 defensive towers, 7 gates, 344 throw holes, and 17 combat chambers in the top of defensive towers. ${ }^{46}$

\footnotetext{
${ }^{43}$ Nimrod Luz, The Mamluk City in the Middle East: History, Culture, and the Urban Landscape, Cambridge: Cambridge University Press, 2014, 74.

${ }^{44}$ Yahaya Waziri, Tatawour Omrani Wa Turath Me'amari Fi Madinah Al-Quds Ash-Shareef, Cairo: Dar Thaqafiyyah Le-Nasher, 2005, 112-114.

${ }^{45}$ Catraine Brebbia \& Vonda Echarri, Structural Studies, Repairs and Maintenance of Heritage Architecture XV, Southampton: WIT Press, 2017, 165-167.

${ }^{46}$ Johann Büssow, "Ottoman reform and urban government in the district of Jerusalem, 1867 -
} 
The Influence of Ottoman Empire on the conservation of the architectural heritage... (Ziad M. Shehada)

The wall was reconstructed by Egyptians and Levantine workers, not Turks. Also, the defensive constructive system was similar to that of the Middle Ages under Ayyubid rule. Re-establishment of the wall is considered one of the largest and greatest projects executed during the Ottoman period over four centuries, due to its massive size, expense, length of construction, durability, number of engineers, technicians, and workers.
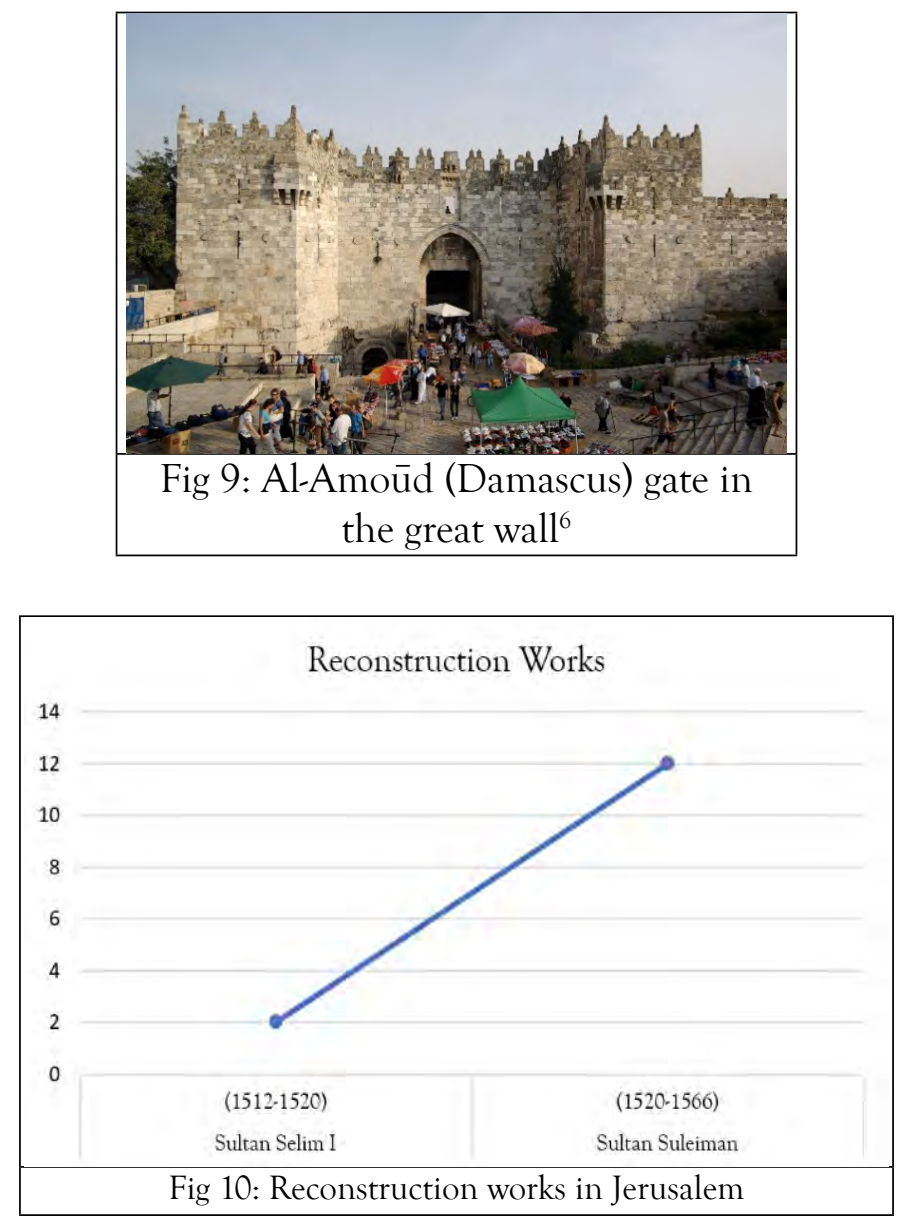

1917", in Urban Governance Under the Ottomans: Between Cosmopolitanism and Conflict, London: Routledge Publishers, 2014, 39-42. 
It is worth mentioning that the reconstruction works started by Sultan Selim I and reached the peak during Sultan Suleiman rule. Also, no reconstruction works were done after that by any of sultans because of the variation of priority and the concentration on expansion at the expense of city development of the cities.

\section{Rehabilitation}

In Jerusalem, the Ottomans carried out several operations with regard to rehabilitation, aiming to revive obsolete elements, preserving Al-Haram Al-Sharif, and delivering it to future generations better than it was. Rehabilitation is defined as "an action or process of making possible a continuing or compatible contemporary use for a historic place, or of an individual component, through repair, alterations and/or additions, while protecting its heritage". ${ }^{47}$ The first rehabilitation project undertaken in Jerusalem was to convert the Church of the Last Supper outside the gate of Nabi Dawood into a mosque. The Arabic text chiseled on the Nabi Dawood tomb confirms that the church and its Franciscan Monastery were converted to a situation fitting in with Islam. ${ }^{48}$

However, providing Al-Haram Al-Sharif with water and re-using the five water sabils was the most important rehabilitation in Jerusalem. There are sabil on the south side of Al-Sultan pond, and the inscription engraved above it indicates that it was established by order of Sultan Suleiman and traced back to $29^{\text {th }}$ June $1536 .{ }^{49}$ This construction was accomplished in only half a year, and the water canal reached the parallel road on the west side of AlHaram. After three weeks, on $4^{\text {th }}$ January 1537 , the water reached to Sabil

\footnotetext{
${ }^{47}$ Pere Roca; Paulo Lourenço \& Angelo Gaetani, Historic Construction and Conservation: Materials, Systems and Damage, Florida: CRC Press, 2019, 67-69.

${ }^{48}$ Evliya C,elebi; Robert Dankoff \& Sooyong Kim, An Ottoman Traveller: Selections from the Book of Travels of Evliya Çelebi, London: Eland publishing limited, 2011, 44-46.

${ }^{49}$ Archie Walls, "Ottoman Restorations to the Sabil and to the Madrasa of Qaytbay in Jerusalem.”, Muqarnas, Volume 10, Number 2 (1993), 154-155.
} 
Al-Selselah gate. Then from that site, a new channel branched towards the southeast on the way of Sabil Al-Ka'as (the cup) north of Al-Aqsa Mosque. Another channel was branched in Al-Haram to the north towards Sabil Al-Busairi (established in Mamluk rule 1436), and then towards Sabil built inside Al-Atm gate. ${ }^{[50]}$ The water reached the area on January $13^{\text {th }} 1537$, i.e. after nine days of opening Sabil Al-Selselah gate. ${ }^{[51]}$ Sabil AI- Nāzir (beholder) gate created in 1537 about $150 \mathrm{~m}$ to the north of Sabil Al-Wad (valley) indicates that rehabilitation of water network and creation public water Sabils were achieved in an amazingly short time not exceeding two months. ${ }^{[52]}$ The design of these foundations refers to the conscious development of the city infrastructure, and the main objective of these facilities was rehabilitating the utilities and providing Al-Haram with water.

As well, Ottomans concentrated their efforts on rehabilitating the social and serving buildings like Ribats. Aladdin Al-Baser Ribat is one of the famous Ribats located on the north side of the road leading to Al-Haram. It was established during Zahir Baybars reign (1267 A.D.) as a place to house the poor, then turned at the beginning of the Ottoman Empire into a prison and later, again to a residence with adding several rooms. ${ }^{[33]}$ Similarly, Kurd Ribat created in 1294 was rehabilitated after destroying some of its parts, and a third floor was added recently to accommodate the pilgrims and visitors coming to Jerusalem, then turned into a house. ${ }^{[54]}$ The Ottomans took care of cultural buildings too, inasmuch as they rehabilitated Al-Tankiziyyah school adjacent to Al-Selselah gate, which was established in 1328 and

\footnotetext{
${ }^{50}$ Katharina Galor \& Hanswulf Bloedhorn, The archaeology of Jerusalem: From the origins to the Ottomans, New Haven: Yale University Press, 2015, 55.

${ }^{51}$ Robert Dankoff, From Mahmud Kaşgari to Evliya Çelebi, Istanbul: Isis Press, 2008, 66-68.

${ }^{52}$ Mohammed Ghoshah, Al-Quds Fi Al-Asr Al-Othmani, Qatar: Ministry of Culture, 2009, 83-84.

${ }^{53}$ Robert Dankoff, From Mahmud Kaşgari to Evliya Çelebi, Istanbul: Isis Press, 2008, 142-144.

${ }^{54}$ Katharina Galor \& Hanswulf Bloedhorn, The archaeology of Jerusalem: From the origins to the Ottomans, New Haven: Yale University Press, 2015, 90-91.
} 
IJIMS: Indonesian Journal of Islam and Muslim Societies, Volume 10, Number 1, June 2020:127-151

considered a unique paradigm for orthogonal planning in Jerusalem. Later, it was converted to an office of Al-Shar' iah Court. ${ }^{55}$ Additionally, in 1915, Jamal Pasha (governor during Sultan Mehmed V rule) converted Al-Salahiiāh school to Islamic College called Slaheddine College, which continued as a modern school until 9th January $1917 .^{56}$
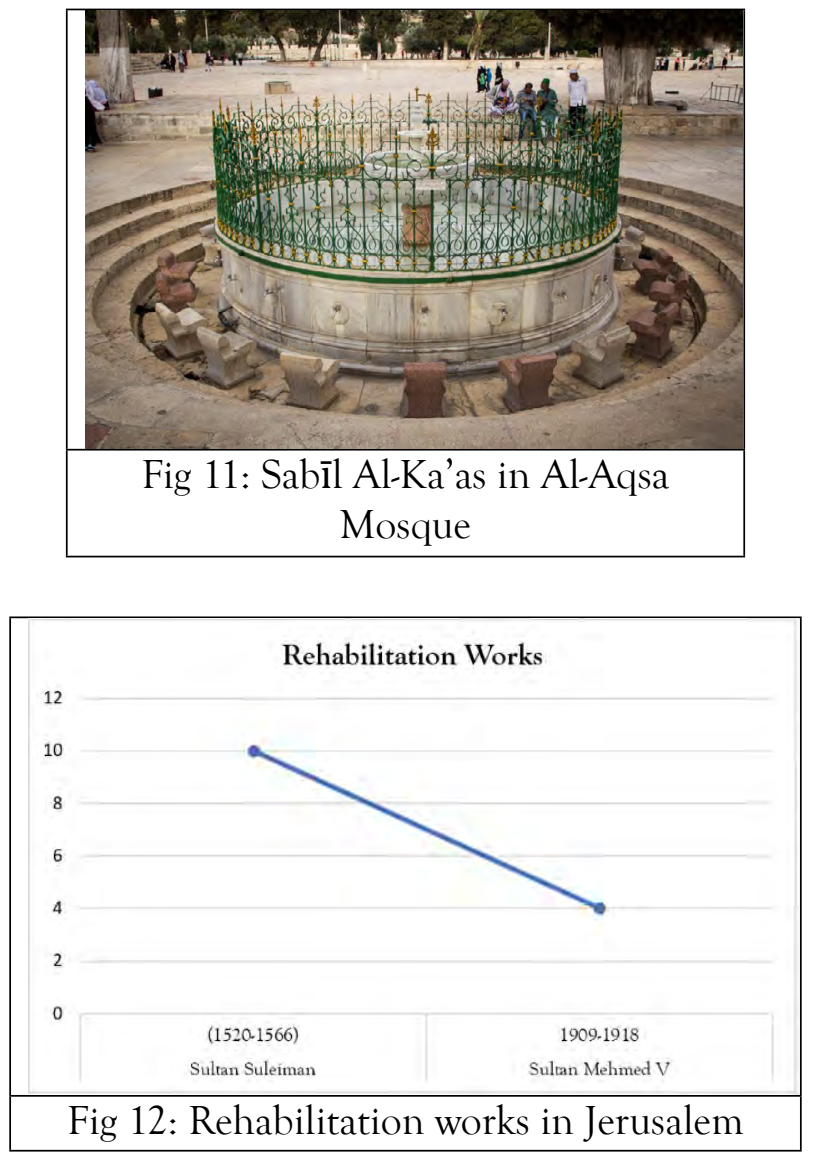

${ }^{55}$ Oleg Grabar \& Said Nuseibeh, The Dome of the Rock, Massachusetts: Belknap Press of Harvard University Press, 2006, 122-123.

${ }^{56}$ Gabor Goston \& Bruce Masters, Encyclopedia of the Ottoman Empire, New York: Facts On File Incorporated, 2010, 99-100. 
It is noticed from the diagram that great efforts exerted by Sultan Suleiman in the rehabilitation field are represented by the declining curve after his era. The work implemented by the Ottomans has been witness to their great services provided to Jerusalem, the most important of which was restoring the citadel and city walls in order to ensure the security of the population; re-activating the water supply to provide the city with fresh water continuously; and expanding trade and industry, leading to the development of Jerusalem as an urban independent center. Meanwhile, they had emphasized the spiritual meanings for the three monotheistic religions during the proceedings of ongoing repairs, in addition to decorating and adorning of the holiest sites in the city, beginning with the shrine of prophet Dawood, and then Al-Haram Al-Sharif. These operations reached to their peak in decorating the Dome of the Rock from the outside with mosaics, giving this central building a brilliant sacrosanct appearance externally reflecting on the whole region.

Thus, it becomes clear how the Ottomans paid attention to the conservation of the architectural heritage of Jerusalem in order to prevent its degradation and leave obvious footprints on one of the holiest parts in the world. These efforts mentioned are just the tip of the iceberg of the works registered and tracked by historians, archaeologists, and architects. Other monuments may have destroyed, disappeared, and not recorded. The prior work can be summarized through the following diagram, which illustrates the types of conservations fulfilled by the most famous Ottoman sultans in Jerusalem. 


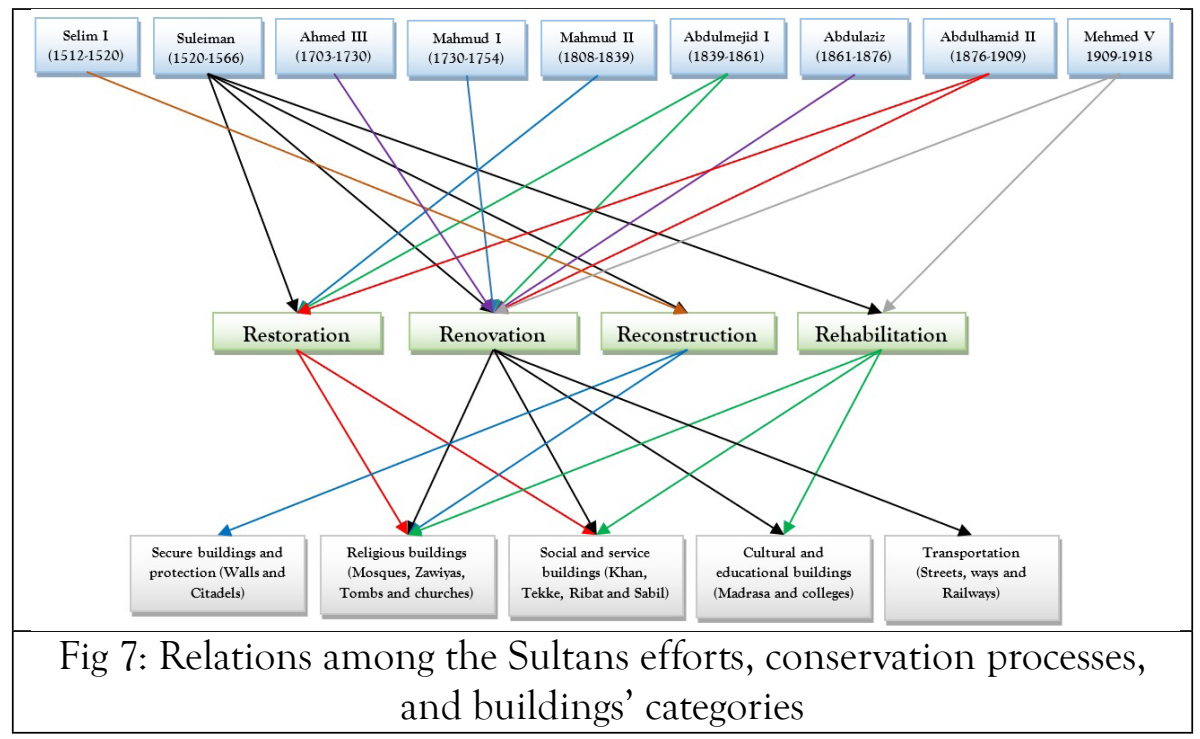

The diagram shows that the renovation approach was at the forefront in the conservation of architectural heritage during the Ottoman rule in Jerusalem. The diagram also illustrates that unrivaled attention paid by Sultan Suleiman Kanūnì (the magnificent) toward Jerusalem in the fourth approaches (renovation, restoration, rehabilitation, and reconstruction). Additionally, the structures most focused on by Ottoman Sultans were religious buildings because of the sanctity and respect in the hearts of people.

\section{Conclusion}

The Ottoman sultans were active keepers of the architectural heritage in Jerusalem throughout their rule. Despite existing in Jerusalem for 400 years, the Ottomans did not establish new Architectural Works especially the mosques because of their respect for the local traditions and the holy places like the Dome of the Rock and Al-Aqsa mosque. Consequently, Ottoman conservation works focused on the 4Rs (Renovation, Restoration, 
Reconstruction and Rehabilitation) respectively in order to achieve multiple goals, ensure that they would be used at the same original purposes, survive the structure to continue alive in the next hundreds of years, to be more wonderful and beautiful, and to leave obvious footprints in the holy city.

The systematic programs applied by the Ottomans to revitalize Jerusalem are considered a new base for further steps of developing the city to become an urban center. In those periods, the number of population had risen, and growing numbers of people coming to the city had been noted to the extent that Sultan Suleiman was prompted to allocate two super-sized buildings to accommodate visitors (Byram Gawish Prince Ribal in year 1540 and Khaski Sultan Tekk in 1552). This gives us an indication that the new attractiveness resulted mainly from the large-scale development programs in the city.

\section{Bibliography}

AbdulKarem, Ibrahim "Al-Mashhad Al-Umrani Fi Al-Quds Khilal Al-Ahd AlOthmani”, Al-Tasamouh, Volume 18, Number 1 (2007): 287-298.

Al-Salim, Farid. Palestine and the Decline of the Ottoman Empire: Modernization and the Path to Palestinian Statehood. London: Bloomsbury Publishing, 2015.

Armstrong, Karen. A History of Jerusalem: One City, Three Faiths. New York: HarperCollins Publishers, 1997.

Auld, Sylvia \& Hillenbrand, Robert. Ottoman Jerusalem: the living city, 1517-1917. London: Altajir World of Islam Trust, 2000.

Barakat, Basher. Al-Quds Ash-Shareef Fi Al-Ahd Al-Othmani. Damascus: Maktabah Dar al-Fikr, 2002.

Brebbia, Catraine, \& Echarri, Vonda. Structural Studies, Repairs and Maintenance of Heritage Architecture XV. Southampton: WIT Press, 2017.

Büssow, Johann, "Ottoman reform and urban government in the district of Jerusalem, 1867-1917”, In Urban Governance Under the Ottomans: Between Cosmopolitanism and Conflict. London: Routledge Publishers, 2014: 97-142.

Çelebi, Evliya; Dankoff, Robert \& Kim, Sooyong. An Ottoman Traveller: Selections from the Book of Travels of Evliya Çelebi. London: Eland Publishing Limited, 
2011.

Cleere, Henry. Archaeological Heritage Management in the Modern World. England: Taylor \& Francis, 2012.

Dankoff, Robert. From Mahmud Ka\gari to Evliya Çelebi. Istanbul: Isis Press, 2008. Dumper, Michael, \& Larkin, Craig. "The politics of heritage and the limitations of international agency in contested cities: A study of the role of UNESCO in Jerusalem's Old City", Review of International Studies, Volume 38, Number 2 (2011): 25-52.

Frank, Rivkah, "Jerusalem Conference on the Digitisation of Cultural Heritage", Library HiTech News, Volume 22, Number 1 (2005): 10-11.

Galor, Katharina \& Bloedhorn, Hanswulf. The archaeology of Jerusalem: From the origins to the Ottomans. New Haven: Yale University Press, 2015.

Ghoshah, Mohammed. Al-Quds Fi Al-Asr Al-Othmani. Qatar: Ministry of Culture, 2009.

Ghلshah, Mohammed. Dirasah Me'mariyah Athariyah Tarikhiyyah: Harat As-Sa'adyah Fi Al-Quds. Ramallah: Syarikat Matba'ah Baitul Maqdis, 1999.

Goston, Gabor \& Masters, Bruce. Encyclopedia of the Ottoman Empire. New York: Facts On File Incorporated, 2010.

Grabar, Oleg \& Nuseibeh, Said. The Dome of the Rock. Massachusetts: Belknap Press of Harvard University Press, 2006.

Hayden, Judy \& Matar, Nabil. Through the Eyes of the Beholder: The Holy Land, 1517-1713. Leiden: Brill publishers, 2012.

Hillenbrand, Robert. The architecture of Ottoman Jerusalem: An introduction. London: Altajir World of Islam Trust, 2002.

ICOMOS. The Burra Charter: The Australia ICOMOS Charter for Places of Cultural Significance 2013. Paris: International Council on Monuments and Sites Publications, 2013.

ISESCO. Newsletter Issued by the Islamic Educational, Scientific, and Cultural Organization, Issues 82-88. Fes: ISESCO publishing center, 2010.

Ishmael, Adam. The Acclaimed Writings of Truth. Indiana: Xlibris Corporation. 2016.

Kark, Ruth. American Consuls in the Holy Land, 1832-1914. Detroit: Wayne State University Press, 1994.

Lemire, Vincent; Tihanyi, Catherine \& Weiss, Lys. Jerusalem 1900: The Holy City in the Age of Possibilities. United States: University of Chicago Press, 2017.

Luz, Nimrod. The Mamluk City in the Middle East: History, Culture, and the Urban Landscape. Cambridge: Cambridge University Press. 2014 
Margoliouth, David \& Tyrwhitt, Walter. Cairo, Jerusalem \&ु Damascus: Three Chief Cities of the Egyptian Sultans. New York: Cosimo Incorporated, 2010. Milwright, Marcus. Dome of the Rock and its Umayyad Mosaic Inscriptions. Edinburgh: Edinburgh University Press, 2016.

O’Neil, Maryvelma, “One giant house': Civil society mobilisation and the protection of Palestinian cultural heritage and identity in Al-Quds AlSharif", Journal of Holy Land and Palestine Studies, Volume 17, Number 1 (2018): 87-113.

Patel, Ismail. Virtues of Jerusalem: An Islamic Perspective. United Kingdom: Al-Aqsa Publications, 2007.

Roca, Pere; Lourenço, Paulo \& Gaetani, Angelo. Historic Construction and Conservation: Materials, Systems and Damage. Florida: CRC Press, 2019.

Rociola, Giuseppe, "The Old City of Jerusalem between heritage and urban renewal: Public buildings and typological aspects”, Key Engineering Materials, Volume 628, Number 3 (2014): 21-26.

Schul, Kent. "Making Jerusalem Ottoman". In Living in the Ottoman Realm: Empire and Identity, 13th to 20th Centuries. USA: Indiana University Press, 2016.

Sinclair, Susan. Bibliography of Art and Architecture in the Islamic World (2 vol. set). Leiden: Brill publishers, 2012.

Sulimani, Gideon \& Kletter, Raz, "Bone Considerations: Archaeology, Heritage, and Ethics at Mamilla, Jerusalem", International Journal of Cultural Property, Volume 24, Number 3 (2017): 321-350.

Thompson, Thomas. Jerusalem in Ancient History and Tradition. London: Bloomsbury Publishing, 2004.

Tütüncü, Mehmet. Turkish Jerusalem (1516-1917): Ottoman Inscriptions from Jerusalem and Other Palestinian Cities. Netherlands: Turkestan and Azerbaijan Research Centre (SOTA), 2006.

Walls, Archie, "Ottoman Restorations to the Sabil and to the Madrasa of Qaytbay in Jerusalem", Muqarnas, Volume 10, Number 2 (1993): 85-97.

Waziri, Yahaya. Tatawour Omrani Wa Turath Me'amari Fi Madinah Al-Quds AshShareef. Cairo: Dar Thaqafiyyah Le-Nasher, 2005. 
